\title{
Coronavirus Persistence on a Plastic Carrier Under Refrigeration Conditions and Its Reduction Using Wet Wiping Technique, with Respect to Food Safety
}

\author{
Hana Malenovská ${ }^{1}$ i
}

Received: 24 July 2020 / Accepted: 7 October 2020 / Published online: 15 October 2020

(c) Springer Science+Business Media, LLC, part of Springer Nature 2020

\begin{abstract}
The global SARS-CoV-2 pandemic dictates that anti-contagion strategies should become matters of essential routine in everyday life. Fomite transference is one of the routes of transmission that has been considered for this virus. However, the risks associated with contaminated surfaces of food packaging kept in refrigerators have not yet been adequately assessed. In this study, a surrogate virus, Alphacoronavirus 1, was used to investigate the persistence of coronavirus dried on a plastic carrier at $4{ }^{\circ} \mathrm{C}$. Techniques of wet wiping, with or without disinfectant saturation, were employed to evaluate their effectiveness in the elimination of the virus. If not wiped, the loss of infectivity of the virus on plastic surfaces was, on average, $0.93 \log _{10}$ (i.e. $83 \%$ ) per day of storage at $4{ }^{\circ} \mathrm{C}$. Wiping with water-saturated material reduced the initial virus titre on the plastic carrier by $2.4 \log _{10}(99.6 \%)$; the same results were achieved through wiping with bactericidal wipes containing ethanol. Wipes saturated with a combination of disinfectant agents (didecyl-dimethyl-ammonium chloride, hydrogen peroxide) decreased the virus titre still more efficiently, by $3.8 \log _{10}(99.98 \%)$ and also significantly prevented further transfer of the virus to a secondary surface through wiping. Thus SARS-CoV-2 transmission potential via contaminated plastic packaging and food may be efficiently eliminated by wet-wiping, especially when wipes saturated with specific disinfectants are used.
\end{abstract}

Keywords Covid-19 · Alphacoronavirus 1 - Surface contamination $\cdot$ Food safety $\cdot$ Virus survival $\cdot$ Refrigerated food

\section{Introduction}

COVID-19 is an infectious respiratory disease caused by the recently discovered SARS-CoV-2 coronavirus. It has now reached pandemic proportions worldwide. SARS-CoV-2 spreads primarily through respiratory secretions, droplets of which may lead to infection through inhalation or via contaminated hands touching the mucosal membranes of the nose, mouth or eyes (Miller and Englund 2020). Fomite transmission probably plays a significant role in indirect infection and transmission of SARS-CoV-2 (Fiorillo et al. 2020; Ren et al. 2020).

There is only limited evidence that virus particles on food products or food packages lead to the disease (Seymour et al.

Hana Malenovská

malenovska@vri.cz

1 Collection of Animal Pathogenic Microorganisms, Veterinary Research Institute, Hudcova 70, 62100 Brno, Czech Republic
2020). However, refrigeration and the plastic materials that make up most packaging provide ideal conditions for the preservation of coronavirus infectivity, since the virus can survive for days in such an environment (Geller et al. 2012; Desai and Aronoff 2020; Eslami and Jalili 2020; Ren et al. 2020). Frequent handling of goods by manufacturers, suppliers, store staff and customers further increases the risk of contamination. Recently, a local outbreak of the SARSCoV-2 from a food store was reported by a press release from the Ministry of Health of the Czech Republic (2020). The outbreak of the virus originated with an infected store employee. Even though all staff and customers were wearing masks when working and shopping, eleven customers (including one who even wore gloves in the shop and bought only a single tub of yogurt) became infected. This suggests that COVID-19 infection due to contaminated food packages may be rare, but it is possible. The Centre of Disease Control and Prevention (CDC) considers COVID-19 infection from handling contaminated food packages low-risk, but nonetheless recommends cleaning and disinfection (Seymour et al. 2020). 
The aim of this study was to investigate coronavirus stability under refrigeration conditions on a plastic surface simulating food packaging and to evaluate the efficiency of a simple method of virus elimination: wet wiping that can be applied in any household. Alphacoronavirus 1 (Fig. 1) was used as a surrogate for SARS-CoV-2. It has previously been employed as a surrogate for SARS-CoV (Casanova et al. 2009; Goyal et al. 2014). In general, members of the same virus family are inactivated similarly under the same physical and chemical stresses (Malenovska 2014), although some differences even between closely related viruses may exist. Nevertheless, Alphacoronavirus 1 and SARS-CoV have been shown to have similar persistence on surfaces (Fiorillo et al. 2020; Kampf et al. 2020) and surface stability of SARS-CoV is markedly similar to SARS-CoV-2 (van Doremalen et al. 2020). Apart from its intrinsically lower risk factor with regard to human health,

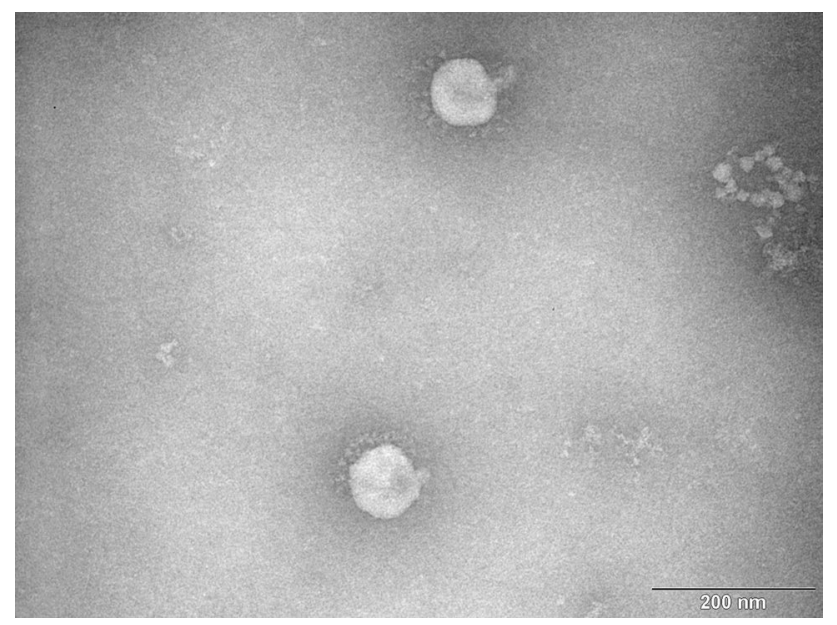

Fig. 1 TEM photograph of viral particles of Alphacoronavirus 1, strain M -42 (CAPM V-126) used in this study as a surrogate for SARS-CoV-2. Virus suspension was applied to a formvar-carboncoated 400-mrsh copper grid, stained with $1 \%$ ammonium molybdate for $1 \mathrm{~min}$ and viewed in a Philips EM 208 transmission electron microscope the suitability of Alphacoronavirus 1 for infectivity experiments consists in its replication to high titres. In contrast, SARS-CoV-2 cultivated in VERO cells achieves only low titres, placing limitations on such experiments (Keil et al. 2020; Sarkale et al. 2020).

\section{Materials and Methods}

\section{Viruses and Cells}

The Alphacoronavirus 1 (strain M 42, CAPM V-126) was obtained from the Collection of Animal Pathogenic Microorganisms (CAPM), incorporated into the National Programme of Protection of Genetic Resources of Economically Significant Microorganisms and Animals of the Czech Republic. The virus was propagated in a PD 5 cell-line obtained from the Centro Substrati Cellulari Laboratory (Brescia, Italy). The cell culture with the virus was cultivated at $37^{\circ} \mathrm{C}$ in Dulbecco's modified Eagle's medium (Biosera, Nuaille, France) supplemented with 3\% heat-inactivated foetal calf serum (HyClone, South Logan, Utah, USA) until complete cytopathology. The virus was then aliquot-divided and frozen at $-80{ }^{\circ} \mathrm{C}$.

\section{Wipes}

All wipes used in the experiments were purchased as hygiene items routinely available in the Czech Republic and were chosen to represent the types of wipes in widespread household use. Three different products were used for the experiments (Table 1): (i) wet wipes containing $99 \%$ water; (ii) wet hygiene wipes containing ethanol (designed for hand and surface hygiene), and (iii) wet wipes for surface disinfection containing didecyl-dimethyl-ammonium chloride and hydrogen peroxide.

Table 1 Wipes used for evaluation of efficacy of removal of SARS-CoV-2 surrogate Alphacoronavirus 1 from a plastic carrier

\begin{tabular}{|c|c|c|c|}
\hline Product & $\begin{array}{l}\text { Wet wipes } \\
\text { Babydream }\end{array}$ & $\begin{array}{l}\text { Hygiene wipes } \\
\text { Balea }\end{array}$ & $\begin{array}{l}\text { Disinfectant wipes } \\
\text { SAVO }\end{array}$ \\
\hline Substances & $\begin{array}{l}99 \% \text { water, caprylyl/capryl glucoside, cit- } \\
\text { ric acid, sodium citrate, sodium benzoate }\end{array}$ & $\begin{array}{l}\text { Water, ethanol ( } 0.6 \mathrm{~g} / \text { wipe })^{*} \text {, glycerine, } \\
\text { Aloe barbadensis leaf extract, chlorhex- } \\
\text { idine digluconate }\end{array}$ & $\begin{array}{l}0.75 \% \text { didecyl-dimethyl-ammonium } \\
\text { chloride, } 0.5 \% \text { hydrogen peroxide, less } \\
\text { than } 5 \% \text { non-ionic surface active agent, } \\
\text { cationic surface active agent, bleach- } \\
\text { ing agent based on oxygen, perfume, } \\
\text { limonene, iodopropynyl butylcarbamate }\end{array}$ \\
\hline Producer & $\begin{array}{l}\text { Produced for Dirk Rossmann GmbH, } \\
\text { Burgwedel, Germany }\end{array}$ & DM-Drogerie Markt, Karlsruhe, Germany & Unilever ČR, Czech Republic \\
\hline
\end{tabular}

* $16.5 \%$ ethanol solution (concentration was calculated based on a comparison of the average weight of wipes before and after warm air-drying) 


\section{Virus Spiking on a Plastic Carrier and Wiping}

A sample of $30 \mu \mathrm{l}$ of the virus $\left(7.5 \log _{10}\right.$ TCID $\left._{50}\right)$ was applied to the middle of the bottom of a $\varnothing 60-\mathrm{mm}$ plastic Petri dish. The drop was lightly dispersed with a pipette tip to form a stain of approximately $0.5 \times 2 \mathrm{~cm}$, and allowed to dry for one hour at room temperature in a biosafety cabinet. Wiping was performed by the same person as follows: a gloved forefinger was covered with the wipe and one single direct wipe, using the fingertip, was performed with a moderate pressure over the whole area of the dried virus spot for $2 \mathrm{~s}$. The Petri dishes were then kept in a refrigerator at $4{ }^{\circ} \mathrm{C}\left( \pm 0.5^{\circ} \mathrm{C}\right)$ before virus elution and titration, which was performed: (i) immediately after virus drying and 5 min after wiping (if applicable), (ii) every $24 \mathrm{~h}$ over 5 consecutive days of storage at $4{ }^{\circ} \mathrm{C}$. All experiments were performed in triplicate.

\section{Virus Elution from the Carrier and Titration}

The virus was eluted from the carrier in $3 \mathrm{ml}$ of Dulbecco's modified Eagle's medium (Biosera, Nuaille, France) at $4{ }^{\circ} \mathrm{C}$, supplemented with $10 \%$ heat-inactivated foetal calf serum (HyClone, South Logan, Utah, USA). The medium was transferred to a Petri dish and the virus left to dissolve for 5 min, after which it was re-suspended using a 5-ml plastic syringe with a needle. The virus suspension was filter-sterilised with a $0.43-\mu \mathrm{m}$ PES syringe filter.

The virus was tenfold serially diluted. Each dilution, at a volume of $100 \mu$ l, was inoculated into five wells of a 48-well microtitration plate with PD 5 cell-culture monolayer. Eight non-inoculated wells were used as negative controls. Culture medium was added after one hour of incubation. The plates were incubated for 5 days at $37{ }^{\circ} \mathrm{C}$ in a $5 \% \mathrm{CO}_{2}$ atmosphere and then the cultures were microscopically examined for virus cytopathic effect. The dilution of suspension that gave rise to cytopathology in half of the cultures (the median tissue culture infective dose, $\log _{10} \mathrm{TCID}_{50} / \mathrm{mL}$ ) was then calculated (Kaerber 1931).

\section{Transfer of the Virus}

To study a possible virus spread to a secondary surface through wiping, virus spiking on a Petri dish and wiping of a virus spot were performed following the same method as specified above. Immediately afterwards, another single direct wipe using the same finger covered with the contaminated wipe was performed across a clean plastic $\varnothing 60-\mathrm{mm}$ Petri dish. Then, the virus was eluted and titrated following the method described above. Experiments with each type of wipe were performed in triplicate.

\section{Virus Inactivation on Wipes}

A drop of $30 \mu \mathrm{l}$ of the virus $\left(7.5 \log _{10} \mathrm{TCID}_{50}\right)$ was distributed over a freshly prepared wipe cut $(2 \times 2 \mathrm{~cm})$ placed on a $\varnothing 60-\mathrm{mm}$ plastic Petri dish. Wipe cuts with the virus were then kept for $5 \mathrm{~min}$ at room temperature in a biosafety cabinet. Subsequently, the virus was eluted from the wipe and titrated. Elution and titration were performed following the same method as the elution from the carrier. To reveal any cytotoxicity of chemicals eluted from wipes that would interfere with cytopathic effect on cell culture during virus titration, virus-free wipe cuts were used as a control in elution and titration. Experiments with each type of wipe were performed in triplicate.

\section{Statistical Analysis}

The virus titres acquired in triplicates are presented as mean \pm SD. Differences in the impacts of the different wipes on virus reduction were tested with one-way ANOVA, followed by Tukey's post-hoc test for pairwise comparisons. Results were considered significant at $P<0.05$. All calculations were performed in Statistica v. 13 (TIBCO Software Inc.).

\section{Results}

The results for coronavirus survival on a plastic carrier are summarised in Table 2. During storage at $4{ }^{\circ} \mathrm{C}$, the average rate of natural inactivation of the virus dried on a plastic surface was $0.93 \pm 0.41 \mathrm{SD} \log _{10} \mathrm{TCID}_{50}$ per day. The virus remained detectable by titration in some of the replications on the 5th day of storage. When the virus was treated by wiping, titres on the carrier decreased dramatically in comparison with the initial titre. The wipes saturated with a combination of disinfectants (Table 1) decreased the virus titre significantly more efficiently than the other wipes (wet and hygiene) at $P<0.05$, by $3.8 \log _{10} \mathrm{TCID}_{50}$. For both wet wipes and hygiene wipes, infectivity decreased by $2.4 \log _{10}$ $\mathrm{TCID}_{50}$ after wiping. The subsequent rate of inactivation of the virus on a carrier that had been previously wiped and kept at $4{ }^{\circ} \mathrm{C}$ was similar to the unwiped control decreasing by less than $1 \log _{10} \mathrm{TCID}_{50}$ per day of storage due to environmental factors.

The average titres of Alphacoronavirus 1 after $5 \mathrm{~min}$ inactivation on the wipes are listed in Table 3. When the virus was spiked on wet wipes containing no disinfectant, the virus recovery achieved on average $7.0 \log _{10} \mathrm{TCID}_{50}$ out of $7.5 \log _{10}$ TCID $_{50}$ of the original virus suspension distributed over the wipe. Wet hygiene wipes saturated with ethanol performed in inactivation of the virus bound to the wipe significantly better than the wet wipes: the virus 
Table 2 Residual titres of SARS-CoV-2 surrogate Alphacoronavirus 1 dried on a plastic carrier and kept in a refrigerator at $4{ }^{\circ} \mathrm{C}$, values in the table correspond to mean \pm SD of $\lg \mathrm{TCID}_{50}$

\begin{tabular}{cllll}
\hline & $\begin{array}{l}\text { Dried virus/no } \\
\text { treatment }\end{array}$ & $\begin{array}{l}\text { Dried virus/wet } \\
\text { wipes** }\end{array}$ & $\begin{array}{l}\text { Dried virus/hygiene } \\
\text { wipes** }\end{array}$ & $\begin{array}{l}\text { Dried virus/ } \\
\text { disinfectant } \\
\text { wipes** }\end{array}$ \\
\hline $\begin{array}{c}\text { Virus recovery before } \\
\text { storage* }\end{array}$ & $7.2 \pm 0.4^{\mathrm{a}}$ & $4.8 \pm 0.7^{\mathrm{b}}$ & $4.8 \pm 0.5^{\mathrm{b}}$ & $3.4 \pm 0.5^{\mathrm{c}}$ \\
$24 \mathrm{~h}$ at $4{ }^{\circ} \mathrm{C}$ & $6.0 \pm 0.4$ & $4.1 \pm 0.9$ & $4.2 \pm 0.8$ & $\leq 2.7$ \\
$48 \mathrm{~h}$ at $4{ }^{\circ} \mathrm{C}$ & $5.6 \pm 0.2$ & $3.0 \pm 0.3$ & $3.4 \pm 0.6$ & $\leq 2.5$ \\
$72 \mathrm{~h}$ at $4{ }^{\circ} \mathrm{C}$ & $4.8 \pm 0.2$ & $\leq 2.6$ & $\leq 3.0$ & $\leq 2.5$ \\
$96 \mathrm{~h}$ at $4{ }^{\circ} \mathrm{C}$ & $3.5 \pm 0.4$ & $\leq 2.5$ & $\leq 2.5$ & $\mathrm{ND}$ \\
$120 \mathrm{~h}$ at $4{ }^{\circ} \mathrm{C}$ & $\leq 2.8$ & $\leq 2.5$ & $\leq 2.5$ & $\mathrm{ND}$ \\
\hline
\end{tabular}

$N D$ not performed

*Virus elution and titration was arranged immediately after visible drying of the virus drop on the carrier and $5 \mathrm{~min}$ after wiping (if applicable)

**Active substances are listed in Table 1

${ }^{a b c}$ Values with different letters indicate significant differences between treatments at $P<0.05$ (one-way ANOVA and post-hoc Tukey's test)
Table 3 Inactivation of SARS-CoV-2 surrogate Alphacoronavirus 1 distributed over wipes at RT and virus spread to a secondary surface through wiping, values in the table correspond to mean $\pm \mathrm{SD}$ of $l g$ $\mathrm{TCID}_{50}$

\begin{tabular}{llll}
\hline & Wet wipes* & Hygiene wipes* & $\begin{array}{l}\text { Disin- } \\
\text { fectant } \\
\text { wipes* }\end{array}$ \\
\hline $\begin{array}{l}\text { Residual titres after } 5 \text { min } \\
\text { inactivation on wipes }\end{array}$ & $7.0 \pm 0.3^{\mathrm{a}}$ & $5.7 \pm 0.2^{\mathrm{b}}$ & $\leq 3.5^{\mathrm{c}}$ \\
$\begin{array}{l}\text { Spread to a secondary } \\
\text { surface }\end{array}$ & $3.0 \pm 0.4^{\mathrm{a}}$ & $2.8 \pm 0.2^{\mathrm{a}}$ & $\leq 2.5^{\mathrm{a}}$ \\
\hline
\end{tabular}

*Active substances are listed in Table 1

${ }^{a b c}$ Different letters indicate significant differences between results of different wipes at $P<0.05$ (one-way ANOVA, Tukey's post-hoc test)

recovery was in average $5.7 \log _{10} \mathrm{TCID}_{50}$. The virus titres after 5 min inactivation on disinfectant wipes were under the detection limit of $3.5 \log _{10} \mathrm{TCID}_{50}$. This limit was caused by the cytotoxicity of the chemicals eluted from the wipes that interfered with the virus titration.

The results of the experimental virus transfer to a secondary surface through wiping are listed in Table 3. The quantities of the virus detected on the surface after wiping with contaminated wet and hygiene wipes did not differ significantly, being on average 3.0 and $2.8 \log _{10}$ TCID $_{50}$, respectively. Transfer of the virus through wiping with disinfectant wipes was not confirmed, as the results were under the detection limit of $2.5 \log _{10} \mathrm{TCID}_{50}$.

\section{Discussion}

The persistence of the coronavirus on a plastic carrier simulating contaminated food packages stored in a refrigerator at $4{ }^{\circ} \mathrm{C}$ was investigated herein using a SARS-CoV-2 surrogate
Alphacoronavirus 1. In agreement with the findings of previous studies (Geller et al. 2012; Ren et al. 2020), these results confirmed high coronavirus persistence, especially at a low temperature and on a plastic surface; this persistence is higher even in comparison with other enveloped respiratory viruses, e. g. the influenza virus (Otter et al. 2016; Zhang and Li 2018). However, according to Mullis et al. (2012), the infectivity of Betacoronavirus 1 on the surface of romaine lettuce under household refrigeration conditions extended to 14 days. Fomite transmission of viral respiratory diseases, including coronaviruses and less persistent viruses, has been previously proven or suspected (Boone and Gerba 2007; Xiao et al. 2017). Those findings support the possibility of COVID-19 spread through food and food packaging.

The second aim of this study was to investigate the efficacy of wet-wiping in removing the virus contamination from a plastic surface, and specifically to determine any differences between wiping with or without disinfectants. An efficient reduction, of $2.4 \log _{10}$ (99.6\%), of the virus was achieved with a single direct wipe over the contaminated area even with a wipe containing no disinfectant. Similarly, wet wiping has been proven as an efficient tool for removing coronavirus from the hands (Ma et al. 2020). Hygienic wipes containing 16.5\% ethanol (Table 1) gave the same results as wet wipes. Wiping is a short duration activity and the virucidal effect of disinfectant is required within seconds (Verhaelen et al. 2014). Ethanol is widely assumed to be very effective against coronaviruses, especially at concentrations of around $70 \%$ with a contact time of $30 \mathrm{~s}$ or longer (Geller et al. 2012). Ethanol in the formulation tested here had no effect on the reduction of the virus during wiping from the surface. In the concentration tested, it had also no effect on the transfer of the virus to another surface if the latter was wiped immediately after the contamination of the wiping cloth, which supports previous findings (Kampf 2018). On the other hand, a longer exposure (5 min), when 
the virus was bound to the hygienic wipe, resulted in a significant reduction of the virus in comparison with wet wipes. Therefore, certain reduction of the risk of further transfer of the virus to another surface during wiping was proven even for wipes containing $16.5 \%$ ethanol. Surface disinfectant wipes containing a combination of disinfectant agents, including didecyl-dimethyl-ammonium chloride and hydrogen peroxide (Table 1), reduced Alphacoronavirus 1 significantly more effectively than the other wipes tested. Both the disinfectant agents mentioned have been demonstrated as active against coronavirus in concentrations used in experiments in this study (Pratelli 2007; Kampf et al. 2020; Lin et al. 2020). Disinfectant wipes were also the only product tested that reduced the virus under the detection limit after 5 min binding to the wipes. Furthermore, the virus was undetectable also after a transfer to a secondary surface through wiping with a contaminated disinfectant wipe. The significance of the use of disinfectants to prevent a transfer of the virus to a larger surface is in accordance with previous findings (Barker et al. 2004).

The results of this study reveal the possible benefit of cleaning and disinfection of food and food packages before their use or storage in a refrigerator, a procedure that has also been recommended by the CDS (Seymour et al. 2020). Wet wiping using readily-available drugstore products for the household appears to be an efficient cleaning method for reduction of any SARS-CoV-2 transmission risk that may arise out of contaminated plastic packaging and food. Satisfactory reduction of the virus can be achieved even with wipes lacking any disinfectant, thus leaving no toxic residues. However, to prevent any transfer of the virus through contaminated wipes to other surfaces, the saturation of the wipes with a combination of disinfectants in sufficient concentrations is crucial. Furthermore, the wipes should be changed frequently and discarded to keep the effect of wiping optimal and minimise cross-contamination and transfer of the virus.

Acknowledgements Igor Malenovsky (Brno) and two anonymous reviewers are thanked for useful comments on an earlier version of the manuscript. Tony Long (Dalmellington) helped work up the English. The paper was supported by the Ministry of Agriculture of the Czech Republic, Institutional support MZE-RO0518.

\section{Compliance with ethical standards}

Conflict of interest The author declares that she has no conflict of interest.

\section{References}

Barker, J., Vipond, I. B., \& Bloomfield, S. F. (2004). Effects of cleaning and disinfection in reducing the spread of Norovirus contamination via environmental surfaces. Journal of Hospital Infection, 58(1), 42-49. https://doi.org/10.1016/j.jhin.2004.04.021
Boone, S. A., \& Gerba, C. P. (2007). Significance of fomites in the spread of respiratory and enteric viral diseases. Applied and Environmental Microbiology, 73(6), 1687-1696. https://doi. org/10.1128/AEM.02051-06

Casanova, L., Rutala, W. A., Weber, D. J., \& Sobsey, M. D. (2009). Survival of surrogate coronaviruses in water. Water Research, 43(7), 1893-1898.

Desai, A. N., \& Aronoff, D. M. (2020). Food safety and COVID-19. JAMA. https://doi.org/10.1001/jama.2020.5877

Eslami, H., \& Jalili, M. (2020). The role of environmental factors to transmission of SARS-CoV-2 (COVID-19). AMB Express. https ://doi.org/10.1186/s13568-020-01028-0

Fiorillo, L., Cervino, G., Matarese, M., D’Amico, C., Surace, G., Paduano, V., et al. (2020). COVID-19 surface persistence: A recent data summery and its importance for medical and dental settings. International Journal of Environmental Research and Public Health. https://doi.org/10.3390/ijerph17093132

Geller, Ch., Varbanov, M., \& Duval, R. E. (2012). Human coronaviruses: Insights into environmental resistance and its influence on the development of new antiseptic strategies. Viruses, 4(11), 3044-3068. https://doi.org/10.3390/v4113044

Goyal, S. M., Chander, Y., Yezli, S., \& Otter, J. A. (2014). Evaluating the virucidal efficacy of hydrogen peroxide vapour. Journal of Hospital Infection, 86(4), 255-259. https://doi.org/10.1016/j. jhin.2014.02.003

Kaerber, G. (1931). Beitrag zur Kollektiven Behandlung Pharmakologischer Reihenversuche. Archive für Experimentelle Pathologie und Pharmakologie, 162, 480-487.

Kampf, G. (2018). Efficacy of ethanol against viruses in hand disinfection. Journal of Hospital Infection, 98(4), 331-338. https://doi. org/10.1016/j.jhin.2017.08.025

Kampf, G., Todt, D., Pfaender, S., \& Steinmann, E. (2020). Persistence of coronaviruses on inanimate surfaces and their inactivation with biocidal agents. Journal of Hospital Infection, 104(3), 246-251. https://doi.org/10.1016/j.jhin.2020.01.022

Keil, S. D., Ragan, I., Yonemura, S., Hartson, L., Dart, N. K., \& Bowen, R. (2020). Inactivation of severe acute respiratory syndrome coronavirus 2 in plasma and platelet products using a riboflavin and ultraviolet light-based photochemical treatment. Vox Sanguinis. https://doi.org/10.1111/vox.12937

Lin, Q., Lim, J. Y. C., Xue, K., Yew, P. Y. M., Owh, C., Chee, P. L., et al. (2020). Sanitizing agent for virus inactivation and disinfection. View. https://doi.org/10.1002/viw2.16

Ma, Q. X., Shan, H., Zhang, H. L., Li, G. M., Yang, R. M., \& Chen, J. M. (2020). Potential utilities of mask-wearing and instant hand hygiene for fighting SARS-CoV-2. Journal of Medical Virology. https://doi.org/10.1002/jmv.25805

Malenovska, H. (2014). The influence of stabilizers and rates of freezing on preserving of structurally different animal viruses during lyophilization and subsequent storage. Journal of Applied Microbiology, 117, 1810-1819. https://doi.org/10.1111/jam.12654

Miller, R., \& Englund, K. (2020). Transmission and risk factors of COVID-19. Cleveland Clinic Journal of Medicine. https://doi. org/10.3949/ccjm.87a.ccc029

Ministry of Health of the Czech Republic. (2020). A press conference on continuous evaluation of the progression of the epidemic, preliminary results of a study on collective immunity and further conception of regional testing for covid-19. Retrieved May 6, 2020, from https://koronavirus.mzcr.cz/tiskova-konference-k-prube znemu-vyhodnoceni-vyvoje-epidemie-predbeznym-vysledkumstudie-kolektivni-imunity-a-k-dalsi-koncepci-regionalniho-testo vani-na-covid-19/.

Mullis, L., Saif, L. J., Zhang, Y., Zhang, X., \& Azevedo, M. S. P. (2012). Stability of bovine coronavirus on lettuce surfaces under household refrigeration conditions. Food Microbiology, 30(1), 180-186. https://doi.org/10.1016/j.fm.2011.12.009 
Otter, J. A., Donskey, C., Yezli, S., Douthwaite, S., Goldenberg, S. D., \& Weber, D. J. (2016). Transmission of SARS and MERS coronaviruses and influenza virus in healthcare settings: The possible role of dry surface contamination. Journal of Hospital Infection, 92, 235-250. https://doi.org/10.1016/j.jhin.2015.08.027

Pratelli, A. (2007). Action of disinfectants on Canine coronavirus replication in vitro. Zoonoses and Public Health, 54(9-10), 383-386. https://doi.org/10.1111/j.1863-2378.2007.01079.x

Ren, S. Y., Wang, W. B., Hao, Y. G., Zhang, H. R., Wang, Z. C., Chen, Y. L., et al. (2020). Stability and infectivity of coronaviruses in inanimate environments. World Journal of Clinical Cases, 8(8), 1391-1399. https://doi.org/10.12998/wjcc.v8.i8.1391

Sarkale, P., Patil, S., Yadav, P. D., Nyayanit, D. A., Sapkal, G., Baradkar, S., et al. (2020). First isolation of SARS-CoV-2 from clinical samples in India. Indian Journal of Medical Research, 151(2 \& 3), 244-250. https://doi.org/10.4103/ijmr.IJMR_1029_20

Seymour, N., Yavelak, M., Christian, C., Chapman, B., \& Danyluk, M. (2020). COVID-19 FAQ for food service: Receiving and food packaging. EDIS 2020. https://edis.ifas.ufl.edu/pdffiles/FS/FS337 00.pdf.

van Doremalen, N., Bushmaker, T., Morris, D. H., Holbrook, M. G., Gamble, A., Williamson, B. N., et al. (2020). Aerosol and surface stability of HCoV-19 (SARS-CoV-2) compared to SARS-CoV-1. The New England Journal of Medicine, 382(16), 1564-1567. https ://doi.org/10.1056/NEJMc2004973

Verhaelen, K., Bouwknegt, M., Rutjes, S., de Roda Husman, A. M., \& Duizer, E. (2014). Wipes coated with a singlet-oxygen-producing photosensitizer are effective against human influenza virus but not against norovirus. Applied and Environmental Microbiology, 80(14), 4391-4397. https://doi.org/10.1128/AEM.01219-14

Xiao, S., Li, Y., Wong, T. W., \& Hui, D. S. C. (2017). Role of fomites in SARS transmission during the largest hospital outbreak in Hong Kong. PLoS ONE. https://doi.org/10.1371/journal.pone.0181558

Zhang, N., \& Li, Y. (2018). Transmission of Influenza A in a student office based on realistic person-to-person contact and surface touch behaviour. International Journal of Environmental Research and Public Health. https://doi.org/10.3390/ijerph15081699

Publisher's Note Springer Nature remains neutral with regard to jurisdictional claims in published maps and institutional affiliations. 